\title{
Evaporative water loss and dehydration during the night in hummingbirds
}

\author{
Pérdida de agua evaporativa y deshidratación nocturna en picaflores
}

\author{
BRADLEY HARTMAN BAKKEN ${ }^{1, *} \&$ PABLO SABAT ${ }^{2,3}$
}

\begin{abstract}
${ }^{1}$ Department of Zoology and Physiology, University of Wyoming, Laramie, Wyoming 82071, USA
${ }^{2}$ Departamento de Ciencias Ecológicas, Facultad de Ciencias, Universidad de Chile, Casilla 653, Santiago, Chile ${ }^{3}$ Center for Advanced Studies in Ecology and Biodiversity, Pontificia Universidad Católica de Chile, Santiago, Chile *e-mail for correspondence: bradley@uwyo.edu
\end{abstract}

\begin{abstract}
Nectar-feeding birds oscillate between avoiding overhydration when they are feeding and preventing dehydration during fasts. Here, we examined how resting rates of total evaporative water loss (TEWL) and metabolic water production (MWP) influence water balance in the green-backed firecrown (Sephanoides sephanoides), a Chilean hummingbird. We hypothesized that a circadian rhythm in TEWL would assuage the dehydration risk that hummingbirds face during the night. However, we did not find support for this idea. In resting hummingbirds, rates of TEWL during the day $\left(54 \pm 6 \mu \mathrm{L} \mathrm{h}^{-1}, \mathrm{n}=8\right)$ and night $\left(65 \pm 12 \mu \mathrm{L} \mathrm{h}^{-1}, \mathrm{n}=5\right)$ were similar. Rates of MWP were also similar between the day $\left(22 \pm 3 \mu \mathrm{L} \mathrm{h}^{-1}, \mathrm{n}=8\right)$ and night $\left(23 \pm 2 \mu \mathrm{L} \mathrm{h}^{-1}\right.$, $\mathrm{n}=5$ ). MWP rates were significantly lower than TEWL rates during both the day and night. Our findings both support the notion that hummingbirds dehydrate during extended fasts and illustrate that evaporative water loss is an important osmoregulatory consideration in hummingbirds. However, because the technique we used to estimate rates of TEWL and MWP at night was indirect, our findings should be interpreted cautiously until direct measurements are available.
\end{abstract}

Key words: circadian rhythm, evaporative water loss, hummingbird, osmoregulation, water balance.

\section{RESUMEN}

Las aves nectarívoras oscilan entre la sobrehidratación durante los períodos de alimentación y la prevención de la deshidratación durante el ayuno. Examinamos cómo las tasas de pérdida total de agua evaporativa (TEWL) y la producción de agua metabólica (MWP) durante el descanso influyen sobre el balance hídrico en el picaflor chileno (Sephanoides sephanoides). Hipotetizamos que el ritmo circadiano en la TEWL podría disminuir el riesgo de deshidratación que los picaflores enfrentan durante la noche. Sin embargo, no encontramos apoyo de esta hipótesis. En los picaflores en reposo, las tasas de TEWL durante el día (54 \pm 6 $\left.\mu \mathrm{L} \mathrm{h}^{-1}, \mathrm{n}=8\right)$ y la noche $\left(65 \pm 12 \mu \mathrm{L} \mathrm{h}^{-1}, \mathrm{n}=5\right)$ fueron similares. Las tasas de MWP también fueron similares durante el día $\left(22 \pm 3 \mu \mathrm{L} \mathrm{h}^{-1}, \mathrm{n}=8\right)$ y la noche $\left(23 \pm 2 \mu \mathrm{L} \mathrm{h}^{-1}, \mathrm{n}=5\right)$. Independiente del período de medición las tasas de MWP fueron significativamente menores que las tasas de TEWL. Nuestros resultados apoyan la noción de que los picaflores se deshidratan durante períodos de ayuno prolongado y además ilustran que la pérdida de agua evaporativa es una consideración osmorregulatoria importante en picaflores. Sin embargo, debido a que la técnica que utilizamos para estimar las tasas de TEWL y MWP fue indirecta, nuestros hallazgos debieran ser interpretados con precaución hasta que medidas directas estén disponibles.

Palabras clave: balance hídrico, pérdida de agua evaporativa, picaflor, osmorregulación, ritmo circadiano.

\section{INTRODUCTION}

Subsisting on floral nectar poses an osmoregulatory dilemma for vertebrates. When feeding, nectarivorous birds ingest multiples of their body mass $\left(\mathrm{M}_{\mathrm{B}}\right)$ per day in water (Beuchat et al. 1990, McWhorter \& López-Calleja 2000,
Martínez del Río et al. 2001) yet appear prone to rapid dehydration during fasts (Hartman Bakken et al. 2004, Lotz \& Martínez del Río 2004). Although recent studies have illuminated how the endocrine (Fleming et al. 2004a, 2004b), intestinal (McWhorter et al. 2003), and renal systems respond to this 
quandary (Goldstein \& Bradshaw 1998, Hartman Bakken et al. 2004, McWhorter et al. 2004, Hartman Bakken \& Sabat 2006), the osmoregulatory role of evaporative water loss remains relatively unstudied (Nicolson 2006). Here, we measure daytime and estimate nighttime rates of total evaporative water loss (TEWL) and metabolic water production (MWP) in resting green-backed firecrowns (Sephanoides sephanoides Lesson, 1827), a hummingbird (Trochilidae) widely distributed in Chile.

A suite of physiological processes in nectarfeeding birds exhibit diel variation, and the apparent rhythms in evaporative water loss (Collins et al. 1980, Collins 1981), metabolism (Collins et al. 1980, Powers 1991), hormone secretion (Fleming et al. 2004a), and renal function (Hartman Bakken et al. 2004, Hartman Bakken \& Sabat 2006) putatively reflect these birds' need for water elimination and conservation during feeding and fasting, respectively. Understanding if and how evaporative water losses are regulated is of interest because modulations could lessen the risk of dehydration these birds confront during nonfeeding periods. Because TEWL appears to reflect hydration status (MacMillen \& Hinds 1998), time of day (Withers 1992, MacMillen \& Hinds 1998), and environmental conditions (Williams 1996, Tieleman et al. 2002, Sabat et al. 2006), we predicted that resting TEWL rates would be greater during the day compared to the night. If supported, this hypothesis suggests the need to conserve body water at night is facilitated by a reduced rate of TEWL. Additionally, we used our nighttime estimate of TEWL to gauge the extent of overnight dehydration in hummingbirds.

\section{MATERIAL AND METHODS}

The protocols we followed for this work conformed to the bioethical guidelines for animal care and experimentation established by the Universidad de Chile. Using mist-nets, we captured male green-backed firecrowns in San Carlos de Apoquindo, Región Metropolitana de Santiago, Chile $\left(33^{\circ} 23^{\prime} \mathrm{S}, 70^{\circ} 31^{\prime} \mathrm{W}\right)$. Maintenance conditions for captive hummingbirds were as previously described (Hartman Bakken \& Sabat 2006). During experiments, the scotophase ranged from 11.48 to $11.53 \mathrm{~h}$ per $24 \mathrm{~h}$. All the measurements we describe below were made at $25 \pm 1{ }^{\circ} \mathrm{C}$.

\section{Daytime measurements}

To measure TEWL $\left(\mu \mathrm{L} \mathrm{h}^{-1}\right)$, oxygen consumption $\left(V \mathrm{O}_{2} ; \mathrm{mL} \mathrm{h}^{-1}\right)$, and $\mathrm{MWP}\left(\mu \mathrm{L} \mathrm{h}^{-1}\right)$ in resting green-backed firecrowns $\left(\mathrm{M}_{\mathrm{B}}=5.90\right.$ $\pm 0.86 \mathrm{~g}, \mathrm{n}=8$ ), we followed standard flowthrough respirometry and hygrometry methods (Tieleman et al. 2002, Sabat et al. 2006). We calibrated our respirometry system with chromatographically certified $20 \% \mathrm{O}_{2}$ in $\mathrm{N}_{2}$ (INDURA, Santiago, Región Metropolitana de Santiago, Chile). $\mathrm{H}_{2} \mathrm{O}$-free air was pumped to the stainless steel metabolic chamber $(\sim 1 \mathrm{~L})$ through Bev-A-Line tubing (Thermoplastic Processes, Stirling, New Jersey, USA) at 500 $\mathrm{mL} \mathrm{min}^{-1}$ from a mass flow controller (MFC-2, Sable Systems, Las Vegas, Nevada, USA). This regime is unlikely to produce hypoxic conditions inside the metabolic chamber (McNab 2006). Air leaving the metabolic chamber was sent at a rate of $290 \mathrm{~mL} \mathrm{~min}^{-1}$ through a relative humidity/dewpoint analyzer (RH-200, Sable Systems, Las Vegas, Nevada, USA) then scrubbed of both $\mathrm{H}_{2} \mathrm{O}$ and $\mathrm{CO}_{2}$ before passing through our $\mathrm{O}_{2}$ analyzer (FC10a, Sable Systems, Las Vegas, Nevada, USA). We digitized analogue output from both the relative humidity/dewpoint and $\mathrm{O}_{2}$ analyzers with a Universal Interface II (Sable Systems, Las Vegas, Nevada, USA). Data were recorded using the ExpeData software package (Sable Systems, Las Vegas, Nevada, USA).

To minimize the influence that activity has on rates of TEWL (Collins et al. 1980, Collins 1981, Withers 1992, Lotz \& Nicolson 2002, Lotz et al. 2003) and to enable comparisons between day and night, we obtained measurements from fasting, postabsorptive birds at rest inside of dark metabolic chambers during the photophase. To trap excretory water, birds perched atop a wire-mesh grid above a pool of mineral oil. After steady state conditions were visually evident (Tieleman et al. 2002, Sabat et al. 2006), hummingbirds remained in the metabolic chamber for $20 \mathrm{~min}$. $\mathrm{H}_{2} \mathrm{O}$ vapour pressure and $\mathrm{O}_{2}$ concentration in the air leaving the chamber were averaged over this 20 min period to determine both TEWL and $\mathrm{VO}_{2}$ (Tieleman et al. 2002). Steady state 
was achieved in $2.20 \pm 0.51 \mathrm{~h}(\mathrm{n}=8)$ and trial length was $2.53 \pm 0.51 \mathrm{~h}(\mathrm{n}=8)$. To check that these measurements were obtained from normothermic birds, we measured cloacal temperature using a digital thermometer $( \pm 0.1$ $\left.{ }^{\circ} \mathrm{C}\right)$ and a $\mathrm{Cu}-\mathrm{Cn}$ thermocouple $\left( \pm 0.1{ }^{\circ} \mathrm{C}\right)$ immediately after each trial. Our criterion for normothermia was any cloacal temperature reading $\geq 39.0{ }^{\circ} \mathrm{C}$. We calculated TEWL and absolute humidity after Withers (1977), Williams \& Tieleman (2000), and Lide (2001), respectively. To estimate MWP at rest, we assumed that hummingbirds were oxidizing endogenous lipid (Suarez et al. 1990, Carleton et al. 2006, Welch et al. 2006), $0.57 \mathrm{mg}$ lipid are oxidized per $\mathrm{mL} \mathrm{O}_{2}$ consumed (SchmidtNielsen 1997), and that the catabolism of $1 \mathrm{mg}$ lipid produces $1.07 \mu \mathrm{L} \mathrm{H}_{2} \mathrm{O}$. With these assumptions, resting MWP is:

$\mathrm{MWP}=V \mathrm{O}_{2} \times 0.57 \times 1.07$, equation 1

\section{Nighttime estimates}

To estimate the resting rate of TEWL during the night, we monitored the nighttime rate of $\mathrm{M}_{\mathrm{B}}$ change $\left(\Delta M_{\mathrm{B}}, \mathrm{mg} \mathrm{h}^{-1}\right)$ in green-backed firecrowns $\left(\mathrm{M}_{\mathrm{B}}=5.33 \pm 0.51 \mathrm{~g}, \mathrm{n}=5\right)$ by hanging the only available cage perch from an electronic balance $( \pm 0.01 \mathrm{~g})$. In a fasting hummingbird, $\Delta M_{\mathrm{B}}$ summarizes three separate rates: TEWL, MWP, and lipid oxidation rate $\left(L, \mathrm{mg} \mathrm{h}^{-1}\right)$. Therefore, we estimated resting TEWL indirectly during the night $\left(\mu \mathrm{L} \mathrm{h}^{-1}\right)$ as:

$\mathrm{TEWL}=\Delta M_{\mathrm{B}}+\mathrm{MWP}-L$,

equation 2

where $L$ is the product of $V \mathrm{O}_{2}$ measured during the day as described above and the oxygen consumption to lipid catabolism ratio of 0.5 . This indirect approach assumes that there is no diel variation in $V \mathrm{O}_{2}$ and that birds are normothermic throughout the night phase. To check the latter assumption, we affixed a $\mathrm{Cu}$ $\mathrm{Cn}$ thermocouple $\left( \pm 0.1{ }^{\circ} \mathrm{C}\right)$ to the cage perch and used a digital thermometer $\left( \pm 0.1{ }^{\circ} \mathrm{C}\right)$ to make body temperature estimates as previously described (Hartman Bakken et al. 2004). Briefly, in order to use perching temperature as a proxy for body temperature during the night, we measured the perching temperature and its corresponding cloacal temperature for each bird in a separate experiment. Based on these measurements, a perching temperature of 31.1 $\pm 1.5{ }^{\circ} \mathrm{C}$ (range: $28.5-32.2{ }^{\circ} \mathrm{C}, \mathrm{n}=5$ ) corresponded to our minimum threshold of 39.0 ${ }^{\circ} \mathrm{C}$ for normothermia. However, due to differences in birds' perching styles, we made normothermia determinations on bird-by-bird basis. $M_{B}$ and perching temperature measurements were taken every $0.5 \mathrm{~h}$ throughout the night phase. A drop of $0.1{ }^{\circ} \mathrm{C}$ below each bird's minimum normothermic value was considered hypothermia.

\section{Statistical analyses}

We compared means to hypothesized values with one-sample t-tests; to compare daytime measurements and nighttime estimates, we used paired t-tests. In all other cases, we analyzed data using standard least squares linear regression. We report data as means $\pm \mathrm{SD}$.

\section{RESULTS}

\section{Total evaporative water loss rates}

We found no evidence to support our hypothesis of a TEWL rhythm in resting greenbacked firecrowns: TEWL rates during the day and night were $54 \pm 6(\mathrm{n}=8)$ and $65 \pm 12 \mu \mathrm{L} \mathrm{h}^{-}$ $1(n=5)$, respectively (Fig. 1A). These rates were similar (paired t-test, $\mathrm{t}_{4}=1.33, \mathrm{P}=$ 0.2539 , Fig. 1A). Daytime TEWL was not different from Williams' (1996) allometric expectation of $49 \mu \mathrm{L} \mathrm{h}^{-1}$ for mesic-adapted birds (one-sample t-test, $\mathrm{t}_{7}=2.11, \mathrm{P}=0.0726$ ); however, nighttime TEWL was significantly greater than Williams' (1996) prediction of 46 $\mu \mathrm{L} \mathrm{h}^{-1}$ for mesic-adapted birds (one-sample ttest, $\left.\mathrm{t}_{4}=3.52, \mathrm{P}=0.0244\right)$. Neither day- nor nighttime TEWL were related to either $V_{2}$ (day: $\mathrm{r}^{2}=0.08, \mathrm{P}=0.4978, \mathrm{n}=8$; night: $\mathrm{r}^{2}=$ $0.00, \mathrm{P}=0.9405, \mathrm{n}=5$ ) or $\mathrm{M}_{\mathrm{B}}\left(\right.$ day: $\mathrm{r}^{2}=0.01$, $\mathrm{P}=0.8745, \mathrm{n}=8$; night: $\mathrm{r}^{2}=0.02, \mathrm{P}=0.8393$, $\mathrm{n}=5)$.

\section{Oxygen consumption and lipid oxidation rates}

$V \mathrm{O}_{2}$ during the day was $36.5 \pm 4.1 \mathrm{~mL} \mathrm{O}_{2} \mathrm{~h}^{-1}$ (n $=8$ ); hummingbirds used in our nighttime experiment had an $V \mathrm{O}_{2}$ equal to $37.7 \pm 4.0 \mathrm{~mL}$ $\mathrm{O}_{2} \mathrm{~h}^{-1}(\mathrm{n}=5)$. Mass-specific rates of were 6.2 $\pm 0.8(\mathrm{n}=8)$ and $6.6 \pm 0.5 \mathrm{~mL} \mathrm{O}_{2} \mathrm{~g}^{-1} \mathrm{~h}^{-1}(\mathrm{n}=5)$ 
during the day and night, respectively. These values are greater than the mass-specific basal metabolic rate of $3.17 \mathrm{~mL} \mathrm{O}_{2} \mathrm{~g}^{-1} \mathrm{~h}^{-1}$ previously reported in green-backed firecrowns; however, we obtained our $V \mathrm{O}_{2}$ measurements at $25 \pm 1$ ${ }^{\circ} \mathrm{C}$, which is below this species' lower critical temperature of $28{ }^{\circ} \mathrm{C}$ (López-Calleja \& Bozinovic 1995). Based on our daytime $V \mathrm{O}_{2}$ measurements, nighttime $L$ in green-backed firecrowns was $19 \pm 2 \mathrm{mg} \mathrm{h}^{-1}(\mathrm{n}=5)$.

\section{Metabolic water production rates}

The rates of MWP in resting hummingbirds were $22 \pm 3(\mathrm{n}=8)$ and $23 \pm 2 \mu \mathrm{L} \mathrm{h}^{-1}(\mathrm{n}=5)$ during the day and night, respectively (Fig. 1B). TEWL was significantly greater than MWP during both the day (paired t-test, $\mathrm{t}_{7}=-$ 14.52, $\mathrm{P}<0.0001$ ) and night (paired t-test, $\mathrm{t}_{4}=$
-7.53, $\mathrm{P}=0.0017)$. The day- and nighttime ratios of MWP to TEWL were $0.42 \pm 0.06(\mathrm{n}=$ $8)$ and $0.36 \pm 0.07(n=5)$, respectively. These ratios were not different (paired t-test, $\mathrm{t}_{4}=$ $1.39, \mathrm{P}=0.2360$ ). Please note, however, that our nighttime estimates of TEWL and MWP are not independent (equation 2).

\section{Body temperature}

Cloacal temperature immediately after our daytime trials was $40.6 \pm 0.7{ }^{\circ} \mathrm{C}$ (range: $39.4-$ $41.2{ }^{\circ} \mathrm{C}, \mathrm{n}=8$ ), indicating that birds were normothermic during the measurement period. The assumption of normothermia we made for our nighttime estimates, however, was not satisfied: green-backed firecrowns were hypothermic for $11 \pm 5 \%$ of the night phase $(1.30 \pm 0.57 \mathrm{~h}, \mathrm{n}=5)$. Consequently, the

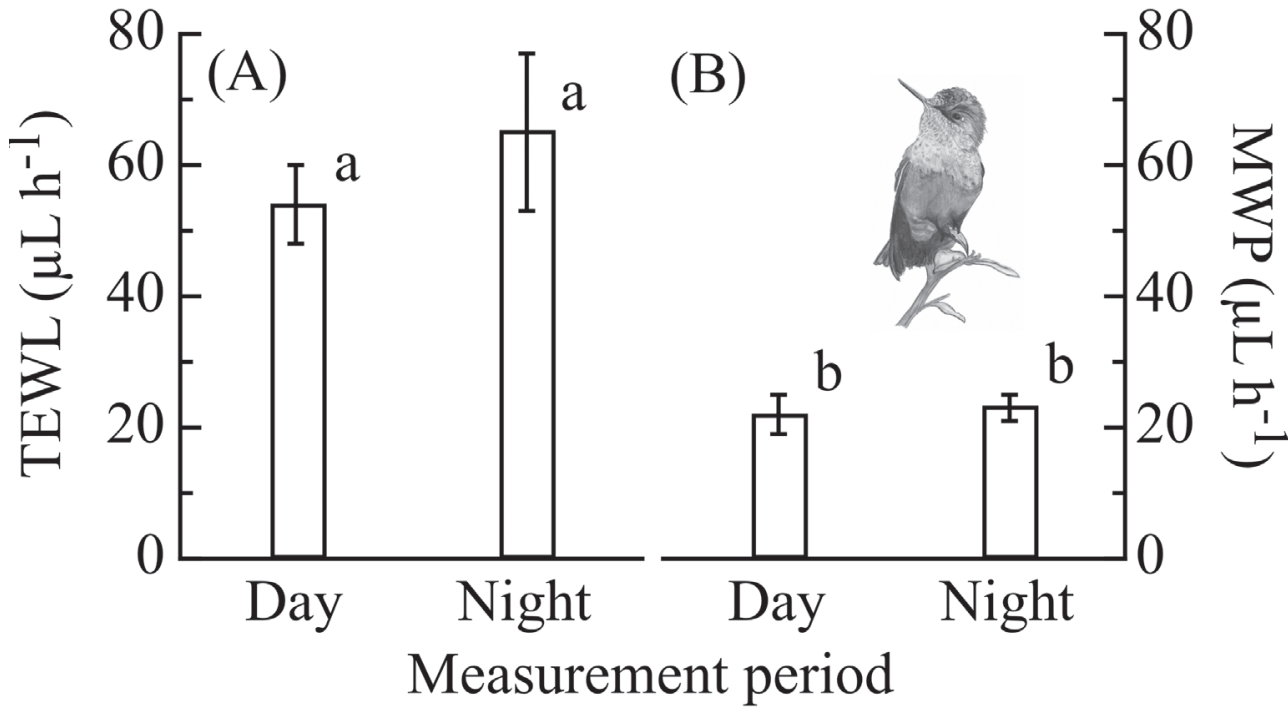

Fig. 1: Total evaporative water loss (TEWL) and metabolic water production (MWP) in resting green-backed firecrowns (Sephanoides sephanoides) during both the day and night. (A) We hypothesized a circadian rhythm in TEWL would facilitate body water conservation at night; however, we did not find any support for this idea. Rates of TEWL were similar during the day $\left(54 \pm 6 \mu \mathrm{L} \mathrm{h}^{-}\right.$ $1, \mathrm{n}=8)$ and night $\left(65 \pm 12 \mu \mathrm{L} \mathrm{h}^{-1}, \mathrm{n}=5\right)$. (B) Although the rates of MWP were significantly lower than rates of TEWL, there was no diel variation in MWP (day: $22 \pm 3 \mu \mathrm{L} \mathrm{h}^{-1}, \mathrm{n}=8$; night: $23 \pm 2$ $\mu L h^{-1}, n=5$ ). Note that the nighttime rates of TEWL and MWP are not independent (equation 2). See Discussion for caveats regarding these findings. Lowercase letters denote significant differences from paired t-tests. Data are means \pm SD.

Pérdida total de agua evaporativa (TEWL) y producción de agua metabólica (MWP) de reposo en picaflores (Sephanoides sephanoides) durante el día y la noche. (A) Hipotetizamos que el ritmo circadiano en la TEWL podría facilitar la conservación del agua corporal durante la noche; sin embargo, no encontramos apoyo para esta idea. Las tasas de TEWL fueron similares durante el día $\left(54 \pm 6 \mu \mathrm{L} \mathrm{h}^{-1}, \mathrm{n}=8\right)$ y la noche $\left(65 \pm 12 \mu \mathrm{L} \mathrm{h}^{-1}, \mathrm{n}=5\right)$. (B) Aun cuando las tasas de MWP fueron significativamente menores que las tasas de TEWL, no hubo variación diaria en la MWP (día: $22 \pm 3 \mu \mathrm{L} \mathrm{h}^{-1}$, $\mathrm{n}=8$; noche: $23 \pm 2 \mu \mathrm{L} \mathrm{h}^{-1}, \mathrm{n}=5$ ). Notar que las tasas de TEWL y MWP nocturnas no son independientes (ecuación 2). Véase Discusión para una advertencia respecto de estos hallazgos. Letras minúsculas denotan diferencias significativas de una prueba pareada de t. Los datos se muestran como promedio \pm DE. 
nighttime rates of TEWL and MWP are overand underestimated, respectively (Withers 1992, Fig. 1). In our discussion, we approximate the magnitude of these inaccuracies. There was no relationship between night length and percent of night spent hypothermic $\left(\mathrm{r}^{2}=0.00, \mathrm{P}=0.9275, \mathrm{n}=5\right)$.

\section{Nighttime changes in body mass}

During the night phase, $\Delta M_{\mathrm{B}}$ in green-backed firecrowns was $-62 \pm 12 \mathrm{mg} \mathrm{h}^{-1}(\mathrm{n}=5)$. Figure $2 \mathrm{~A}$ shows a typical overnight $\mathrm{M}_{\mathrm{B}}$ profile for the hummingbirds in this experiment. On average, birds lost $714 \pm 141 \mathrm{mg}(14 \pm 3 \%$ of initial $\mathrm{M}_{\mathrm{B}} ; \mathrm{n}=5$ ) overnight; however, time spent hypothermic exerted a significant effect on overnight $M_{B}$ loss $\left(y=-965+193 x, r^{2}=0.61\right.$, $\mathrm{P}=0.0045, \mathrm{n}=5$, Fig. 2B).

\section{DISCUSSION}

We suspected that a circadian rhythm in resting TEWL would lessen the risk of nighttime dehydration in hummingbirds; however, we found no evidence to support this hypothesis (Fig. 1A). In our discussion, we first consider the significance that an invariable resting TEWL rate has on the processes hummingbirds use to maintain water balance. We then discuss how nocturnal hypothermia and pre-night hyperphagia in hummingbirds may have affected our nighttime measurements.

\section{Osmoregulatory implications}

An invariable rate of TEWL in resting hummingbirds suggests that, after expected increases in water loss with activity (Collins 1981, Withers 1992, Lotz \& Nicolson 2002, Lotz et al. 2003), the need for water elimination during the day is not assuaged by a higher rate of TEWL. However, with no daily oscillations in resting TEWL (Fig. 1A), the notion that hummingbirds must cope with an extreme risk of dehydration at night is supported. In this study, green-backed firecrowns lost $750 \pm 141$ $\mu \mathrm{L}(\mathrm{n}=5)$ of body water during the night due to evaporation. In terms of total body water (Hartman Bakken \& Sabat 2006), this volume corresponds to a total loss of $25 \pm 5 \%(\mathrm{n}=5)$

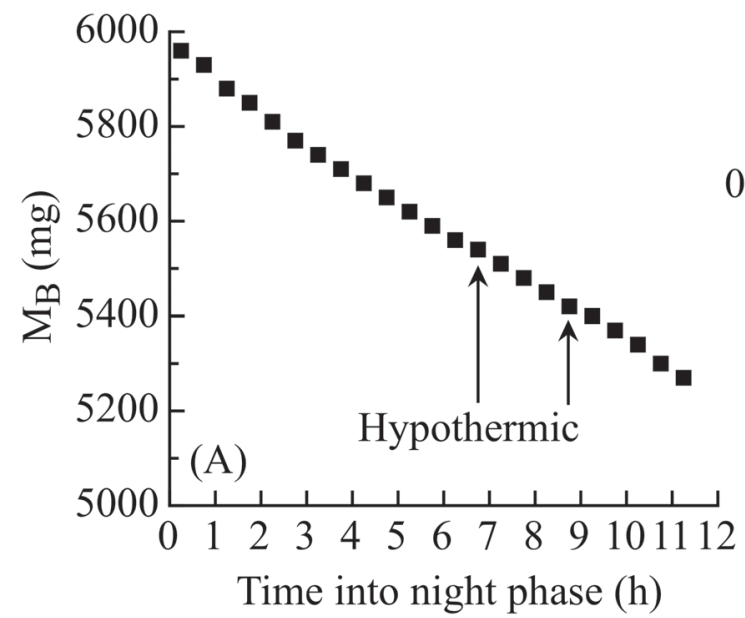

Time hypothermic (h)

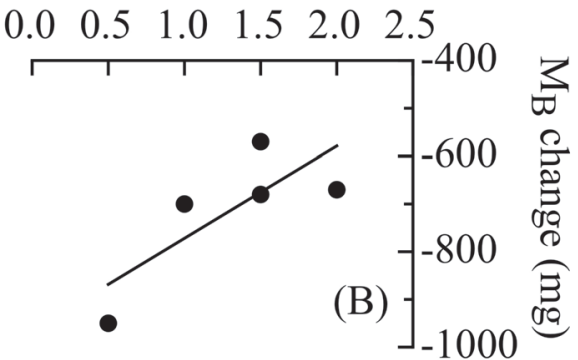

Fig. 2: (A) A nighttime body mass $\left(\mathrm{M}_{\mathrm{B}}\right)$ profile for one representative green-backed firecrown (Sephanoides sephanoides). On average, green-backed firecrowns lost $\mathrm{M}_{\mathrm{B}}$ at a rate of $-62 \pm 12 \mathrm{mg}$ $\mathrm{h}^{-1}(\mathrm{n}=5)$ and were hypothermic for $1.30 \pm 0.57 \mathrm{~h}$ during the night $(11 \pm 5 \%$ of the night phase; $\mathrm{n}$ =5). (B) However, this rate of loss was significantly affected by the time hummingbirds spent hypothermic $\left(\mathrm{y}=-965+193 \mathrm{x}, \mathrm{r}^{2}=0.61, \mathrm{P}=0.0045, \mathrm{n}=5\right)$. The green-backed firecrown in panel (A) was hypothermic during two $0.5 \mathrm{~h}$ measurement periods (denoted by arrows).

(A) Perfil representativo de la masa corporal $\left(\mathrm{M}_{\mathrm{B}}\right)$ en un picaflor (Sephanoides sephanoides). En promedio, los picaflores pierden $\mathrm{M}_{\mathrm{B}}$ a una tasa de $-62 \pm 12 \mathrm{mg} \mathrm{h}^{-1}(\mathrm{n}=5)$ y se mantuvieron hipotérmicos por $1.30 \pm 0.57 \mathrm{~h}$ durante la noche $(11 \pm 5 \%$ de la fase nocturna; $n=5$ ). (B) Sin embargo, esta tasa de pérdida fue significativamente afectada por el tiempo en que los picaflores se mantuvieron hipotérmicos $\left(\mathrm{y}=-965+193 \mathrm{x}, \mathrm{r}^{2}=0.61, \mathrm{P}=0.0045, \mathrm{n}=5\right)$. El picaflor en el panel (A) se mantuvo hipotérmico durante dos períodos de $0.5 \mathrm{~h}$ (indicado por flechas). 
or a loss of $\sim 2 \%$ each hour. If accurate, these values constitute extreme levels of dehydration; however, we explain below why both our nighttime measurements and dehydration estimates are likely exaggerated.

Hypothermia and hyperphagia: direction and magnitude of their effects on our nighttime measurements

The indirect method we used to estimate both TEWL (equation 2) and MWP (equation 1) at night makes two critical assumptions: 1) there is no diel variation in $V \mathrm{O}_{2}$ and 2) hummingbirds are normothermic throughout the night phase. Even though we did not measure nighttime $V \mathrm{O}_{2}$, our observation that hummingbirds were hypothermic for $\sim 10 \%$ of the night phase indicates both assumptions of our indirect technique were violated (Lasiewski 1963, Hainsworth \& Wolf 1970, Withers 1992, López-Calleja \& Bovinovic 1995). What impact did this have on our nighttime measurements? Although we cannot gauge the effect precisely, we can assign maxima to our inaccuracies. If we accept the extreme (and improbable) scenario that $V \mathrm{O}_{2}$ during hypothermic bouts is zero, the rate of TEWL at night will be overestimated by no more than the nighttime percentage of hypothermia $(11 \pm 5$ $\%, \mathrm{n}=5)$. By this reasoning, the range of means for the rate of TEWL at night is 58-65 $\mu \mathrm{L} \mathrm{h}^{-1}$ (Fig. 1A). Using the same rationale, we underestimated nighttime MWP rate by no more than $11 \pm 5 \%(\mathrm{n}=5)$. The range of means for the MWP rate at night, therefore, is $23-26 \mu \mathrm{L} \mathrm{h}^{-1}$ (Fig. 1B). Taking into account these ranges, the range of means for our nighttime MWP to TEWL ratio is $0.35-0.45$. Although this sensitivity analysis suggests our conclusion that hummingbirds do not show a circadian rhythm in TEWL is robust (Fig. 1), our analysis does not consider the effect a nighttime dip in $V \mathrm{O}_{2}$ would have on our estimates (Powers 1991, Withers 1992). Consequently, our findings should be treated cautiously until direct nighttime measurements are available.

Concerning our estimates of nighttime dehydration, the hyperphagic (and thus polydipsic) behaviour of nectar-feeding birds before lights-off in the evening (Collins 1981, López-Calleja et al. 1997) may have caused us to overstate these. That is, there will be a positive relationship between dietary water in nonabsorptive regions of the intestinal tract (i.e., crop) and our estimation of the proportion of total body water lost to evaporation during the night.

Despite the problems discussed above, it is clear that nightly evaporative water loss in hummingbirds is substantial. When considered together with their inability to form concentrated urine (Lotz \& Martínez del Río 2004), it appears that hummingbirds arrest renal filtration at night (Hartman Bakken et al. 2004, Hartman Bakken \& Sabat 2006) in order to prevent a lethal loss of body water. Direct measurements of nighttime TEWL, however, are needed, and coupling them to a study of how body water volumes and osmolarities change over the course of fasting periods would be an informative approach.

\section{ACKNOWLEDGEMENTS}

Annie Hartman Bakken illustrated the firecrown. We are indebted to Paulina González, Maria Victoria López-Calleja, and Alyeska Hayduke for their assistance. Carlos Martínez del Rio's criticisms were memorable and helped us to improve this manuscript. Support for this work was provided by a FONDECYT grant (1050196) to PS. BHB was supported by a National Science Foundation grant (IBN-0110416) to Carlos Martínez del Río and fellowships from the American Ornithologists' Union, The Journal of Experimental Biology, the Society for Integrative and Comparative Biology, and the University of Wyoming.

\section{LITERATURE CITED}

BEUCHAT CA, WA CALDER, III \& EJ BRAUN (1990) The integration of osmoregulation and energy balance in hummingbirds. Physiological Zoology 63: 1059-1081

CARLETON SA, B HARTMAN BAKKEN \& C MARTÍNEZ DEL RÍO (2006) Metabolic substrate use and the turnover of endogenous energy reserves in broad-tailed hummingbirds (Selasphorus platycercus). Journal of Experimental Biology 209: 2622-2627.

COLLINS BG (1981) Nectar intake and water balance for two species of Australian honeyeater, Lichmera indistincta and Acanthorhynchus superciliosis. Physiological Zoology 54: 1-13. 
COLLINS BG, G CARY \& S PAYNE (1980) Metabolism, thermoregulation and evaporative water loss in two species of nectar-feeding birds (family Meliphagidae). Comparative Biochemistry and Physiology 67: 629-635.

FLEMING PA, DA GRAY \& SW NICOLSON (2004a) Circadian rhythm of water balance and aldosterone excretion in the whitebellied sunbird Nectarinia talatala. Journal of Comparative Physiology B 174: 341-346.

FLEMING PA, DA GRAY \& SW NICOLSON (2004b) Osmoregulatory response to acute diet change in an avian nectarivore: rapid rehydration following water shortage. Comparative Biochemistry and Physiology 138A: 321-326.

GOLDSTEIN DL \& SD BRADSHAW (1998) Renal function in red wattlebirds in response to varying fluid intake. Journal of Comparative Physiology B 168: 265-272.

HAINSWORTH FR \& LL WOLF (1970) Regulation of oxygen consumption and body temperature during torpor in a hummingbird, Eulampis jugularis. Science 168: 368-369.

HARTMAN BAKKEN B, TJ MCWHORTER, E TSAHAR \& C MARTÍNEZ DEL RÍO (2004) Hummingbirds arrest their kidneys at night: diel variation in glomerular filtration rate in Selasphorus platycercus. Journal of Experimental Biology 207: 4383-4391.

HARTMAN BAKKEN B \& P SABAT (2006) Gastrointestinal and renal responses to water intake in the green-backed firecrown (Sephanoides sephanoides), a South American hummingbird. American Journal of Physiology 291: R830-R836.

LASIEWSKI RC (1963) Oxygen consumption of torpid, resting, active, and flying hummingbirds. Physiological Zoology 36: 122-140.

LIDE DR (2001) Handbook of chemistry and physics. $82^{\text {nd }}$ edition. CRC Press, Boca Raton, Florida, USA. $2,664 \mathrm{pp}$.

LÓPEZ-CALLEJA MV \& F BOZINOVIC (1995) Maximum metabolic rate, thermal insulation and aerobic scope in a small-sized Chilean hummingbird (Sephanoides sephanoides). Auk 112: 1034-1036.

LÓPEZ-CALLEJA MV, F BOZINOVIC \& C MARTÍNEZ DEL RÍO (1997) Effects of sugar concentration on hummingbird feeding and energy use. Comparative Biochemistry and Physiology 118A: 1291-1299.

LOTZ CN \& C MARTÍNEZ DEL RÍO (2004) The ability of rufous hummingbirds Selasphorus rufus to dilute and concentrate urine. Journal of Avian Biology 35: 54-62.

LOTZ CN, C MARTÍNEZ DEL RÍO \& SW NICOLSON (2003) Hummingbirds pay a high cost for a warm drink. Journal of Comparative Physiology B 173: 455-462.

LOTZ CN \& SW NICOLSON (2002) Nectar dilution increases metabolic rate in the lesser doublecollared sunbird (Nectarinia chalybea). Condor 104: 672-675

MACMILLEN RE \& DS HINDS (1998) Water economy of granivorous birds: California house finches. Condor 100: 493-503.

MARTÍNEZ DEL RÍO C, JE SCHONDUBE, TJ MCWHORTER \& LG HERRERA (2001) Intake responses in nectar feeding birds: digestive and metabolic causes, osmoregulatory consequences, and coevolutionary effects. American Zoologist 41: 902-915.

MCNAB BK (2006) The relationship among flow rate, chamber volume and calculated rate of metabolism in vertebrate respirometry. Comparative Biochemistry and Physiology 145A: 287-294.

MCWHORTER TJ \& MV LÓPEZ-CALLEJA (2000) The integration of diet, physiology, and ecology of nectar-feeding birds. Revista Chilena de Historia Natural 73: 451-460.

MCWHORTER TJ, C MARTÍNEZ DEL RÍO, B PINSHOW (2003) Modulation of ingested water absorption by Palestine sunbirds: evidence for adaptive regulation. Journal of Experimental Biology 206: 659-666.

MCWHORTER TJ, C MARTÍNEZ DEL RÍO, B PINSHOW \& L ROXBURGH (2004) Renal function in Palestine sunbirds: elimination of excess water does not constrain energy intake. Journal of Experimental Biology 207: 3391-3398.

NICOLSON SW (2006) Water management in nectarfeeding birds. American Journal of Physiology 291: R828-R829.

POWERS DR (1991) Diurnal variation in mass, metabolic rate, and respiratory quotient in Anna's and Costa's hummingbirds. Physiological Zoology 64: 850-870.

SABAT $P$, G CAVIERES, C VELOSO \& M CANALS (2006) Water and energy economy of an omnivorous bird: population differences in the rufous-collared sparrow (Zonotrichia capensis). Comparative Biochemistry and Physiology 144A: 485-490.

SCHMIDT-NIELSEN K (1997) Animal physiology: adaptation and environment. Fifth edition. Cambridge University Press, Cambridge, United Kingdom. 607 pp.

SUÁREZ RK, J LIGHTON, C MOYES G BROWN, C GASS \& P HOCKACHKA (1990) Fuel selection in rufous hummingbirds: ecological implications of metabolic biochemistry. Proceedings of the National Academy of Sciences USA 87: 9207-9210.

TIELEMAN BI, JB WILLIAMS \& P BLOOMER (2002) Adaptation of metabolism and evaporative water loss along an aridity gradient. Proceedings of the Royal Society London B 270: 207-214.

WELCH KC, JR, B HARTMAN BAKKEN, C MARTÍNEZ DEL RÍO \& RK SUÁREZ (2006) Hummingbirds fuel hovering flight with newly ingested sugar. Physiological and Biochemical Zoology 79: 10821087.

WILLIAMS JB (1996) A phylogenetic perspective of evaporative water loss in birds. Auk 113: 457-472.

WILLIAMS JB \& BI TIELEMAN (2000) Flexibility in basal metabolic rate and evaporative water loss among hoopoe larks exposed to different environmental temperatures. Journal of Experimental Biology 203: 3153-3159.

WITHERS PC (1977) Measurement of metabolic rate, $\mathrm{VCO}_{2}$, and evaporative water loss with a flowthrough mask. Journal of Applied Physiology 42: 120-123.

WITHERS PC (1992) Comparative animal physiology. Saunders College Publishing, Fort Worth, Texas, USA. 949 pp. 
